\title{
Identification of Fungy on Flour Albus Pathological of Pregnant Woman in Puskesmas Pekauman City Banjarmasin
}

\author{
Dede Mahdiyah $^{\text {a, }}$, Putri Vidiasari ${ }^{\mathrm{b}}$, Junarta Fitriani Simarmata \\ ${ }^{\mathrm{a}, \mathrm{c}}$ Akademi Kebidanan Sari Mulia Banjarmasin \\ ${ }^{\mathrm{b}}$ STIKES Sari Mulia Banjarmasin \\ *Email: mahdiyahdede@yahoo.co.id
}

\begin{abstract}
Background: Infectious diseases are still one of the leading causes of death in the world. One of the infectious agents that often infect humans is a fungal infection. The fungus will cause primary or secondary disease if there is a predisposing factor. One of the predisposing factors is pregnancy. Purpose: This research was to identified the pathological pathogenic fungi of pregnant women in Pekakesmas Pekauman Kota Banjarmasin. Method: The research used is quantitative descriptive research and pregnant women population, sample of 8 pregnant women by using sampling technique using random sampling sample. Result: The result of identification from 8 samples obtained 3 positive samples of Candida fungus, on culture result using Sabouraud Dextore Agar (SDA) media obtained 2 positive samples, on culture result with Germ tube test obtained 2 positive samples of Candida albicans fungus.Keywords-Bumiputera, CRM, Operational CRM, E-CRM, sharia life insurance
\end{abstract}

Keywords: Mushroom, Candida albicans, Pregnant Women, Flour Albus.

\section{Background}

Infectious diseases are still one of the leading causes of death in the world. One of the infectious agents that often infect humans is a yeast infection. The fungus will cause primary or secondary disease if there is a predisposing factor. One of the predisposing factors is pregnancy. Because the risk of infection is greater in pregnant women. Indonesia's tropical climate with high temperature and humidity is a potential place for growth. There are many fungi around us either pathogenic or non-pathogenic. The fungus will cause a primary or secondary disease if there is a predisposing factor that is favorable for the growth of fungi [1].

Whitish or flour albus is a condition when the vagina secretes fluid or mucus that resembles pus caused by germs. Whitish can cause itching, bad smell, and green color [2]. Whitish is caused by matters relating to the behavior of women in maintaining the cleanliness of genetic organs. Many women consider the fluid that comes out of the vagina as a common fluid. Yet according to research $75 \%$ of all women in the world will experience leucorrhoea at least once in a lifetime [3].
Pregnant women are susceptible to infection, because the endurance of pregnant women will usually decrease and increase the need for metabolism. Whitish in pregnant women can lead to high risk of premature rupture of membranes, so that the baby is born prematurely or the baby is born with low birth weight. When labor is the most common effect of abnormal vaginal discharge is infection. Where the liquid contains many white blood cells and the color until yellowish to green. Even often thick out the unpleasant smell. Usually affected by infection are the vulva, vagina, cervix and uterine cavity. Candidiasis is an acute or subacute infection caused by Candida albicans or occasionally by other Candida species, which can invade various tissues [4].

According to WHO Year 2009 that in the United States $31.6 \%$ of pregnant women experience vaginal discharge caused by Candida albicans. In Indonesia, based on the results of research in 2007 in 8 major cities namely Jakarta, Bandung, Surabaya, Semarang, Yogyakarta, Medan, Banjarmasin and Makasar by taking a sample of 1000 pregnant women found 823 people $(82.3 \%)$ who experienced vaginal [3]. Candidiasis is an acute or subacute infection caused by Candida albicans or sometimes by other Candida species, which can invade various tissues [4]. One of the prevention of fluor albus by observing the vulva hygine of pregnant women, especially the genetalia region, Which aims to maintain cleanliness of the vulva, prevent the occurrence of vulvar infections and prevent the entry of microorganisms in urogenital tractus [5].

According to a study conducted by Atmasari in 2011 titled "Candida albicans identification of pregnant women's vaginal fluid at midwife practice clinics with germ tube method" states that of 20 samples of vaginal fluid specimens of pregnant women positive Candida infected, $88.89 \%$ was found in Gestational age entering the third trimester. Suspected estrogen increases Candida's attachment. In the vaginal epithelium and directly increase the virulence of yeast [1]. Research conducted by Widarti in 2009 on vaginal swabs of pregnant women in obstetric and obstetric polyclinics states that $60 \%$ of pregnant women are infected with candida albicans [6].

Based on data from Puskesmas Pekauman Banjarmasin in 2015 from January to December, with 128 pregnant women, 23 positive pregnant women were infected by Candida albican fungi from 52 pregnant women who checked their pregnancy. In 2016 from January to March, 
11 positive people were infected with Candida albican fungi from 29 pregnant women who were examined. Preliminary study results at Pekakesmas Pekauman Banjarmasin on January 6, 2016, there were 22 pregnant women of trimester I, II, III of pregnancy examination, based on the results of data collection through interview, there are 5 people often experience vaginal discharge, 7 people sometimes experience whiteness and 10 people Rarely experience vaginal discharge. Of 5 people who were examined with pathological vaginal discharge 3 positive pregnant women infected Candida albican. The data attracted the attention of researchers to conduct research to identify the fungus on pathological vaginal discharge in Pekakesmas Pekauman Banjarmasin. The data attracted the attention of researchers to conduct research to identify the fungus on pathological vaginal discharge in Pekakesmas Pekauman Banjarmasin.

\section{Materials and Methods}

The tools and materials used in this research are stationery, spriter lamp, mask, microscope, round oce, glass object, glass cover, gloves, $6 \mathrm{~cm}$ reaction tube, catgram (gential violet, lugol, 96\% alcohol, safranin) Media sabouraud dextore agar (SDA), oil immersion, serum. The method used in this research is direct preparation method, culture method, and Germ Tube Test [5].

The principle is the sample of vaginal swab made direct preparations in gram paint then examined under a microscope with 10x and 100x objective lens enlargement, embedded in SDA is also made prep prep with gram paint then examined under a microscope with $100 \times$ objective lens enlargement with oil immersion drop, And germ tube test by adding colonies of SDA media to serum, observed in objective lens enzyme microscope 10x and 40x [5]. Vaginal Swab Taking Procedure is done by approaching pregnant women and explaining the intent and purpose of the study. If the expectant mother has understood the purpose and purpose of this research then given inform consent to be signed. Officers use gloves and masks. Pregnant women are prepared to lie down on the genealogy table with the position of the lysotomy. Performed inspiration, palpation, belly press, groin. Examined pubis and labia searched for existing abnormalities. When many bodies on the vulva are cleansed with DTT cotton. Installed speculum in accordance with the size, when the cervical keys have been found speculum. Taken sterile cotton swabs, taken smear on the vaginal wall (when removing the cotton swabs should not touch anything) for dry preparation by removing the stick in the glass object. Opened speculum, examined $\mathrm{pH}$ with litmus paper. Immediately after the preparation of spritus lights. Planted on Sabouraud Dextore Agar (SDA) media. Lidi Cotton is thrown away in medical bins. Gloves are thrown away and wash hands with soap. Pregnant women are welcome to await the results of the examination [5].

\section{Result}

This research was conducted to Identify Fungi on Pathological Disease of Pregnant Women at Pekakesmas Pekauman Kota Banjarmasin on April 20, 2016 - May 9, 2016 and got the result as in Table 1 .

Table 1 Results of Identification of Candida albicans Fungi on Pathological Disease of Pregnant Women at Pekakesmas Banajarmasin Community Health Center.

\begin{tabular}{|l|l|l|}
\hline \multirow{2}{*}{ Test } & \multicolumn{2}{|l|}{ Result } \\
\cline { 2 - 3 } & Positive & Negative \\
\hline Direct preparate & 3 sample & 5 sample \\
\hline Cultur on SDA & 2 sample & 6 sample \\
\hline Test of Germ Tube & 2 sample & 6 sample \\
\hline
\end{tabular}

Based on Table 1 After the examination on pathological vaginal discharge in pregnant women using direct preparation method by vaginal swab there are 3 positive samples infected with Candida fungus. Then tested with culture on Sabouraud Dextrose Agar (SDA) media to identify the smell of Candida albicans fungi and obtained 2 positive samples, then Germ tube test there are 2 positive samples conducted aim to identify Candida albicans fungi filaments.

\section{Discussion}

The results of the inspection of direct preparations of 8 vaginal swab samples in pregnant women of trimester I, II and III at Pekakesmas Laboratory of Banjarmasin City obtained results of 5 samples not Candida type. 1 positive sample of Candida sp, and 2 positive samples of Candida albicans. From 3 samples were tested using SDA media and Germ Tube test obtained 2 positive samples of Candida albicans and 1 type Candida sp. Results on SDA media obtained the presence of colony fungi growth of cream color and Candida typical smell, this proves that the cause of pathological whiteness of pregnant women is Candida albicans. On direct examination of 2 people with age between 20-35 years, occurs in the third trimester, Grande multi, with a history of vaginal discharge, the baby was born with a weight of 2500-4000 grams, and with a history of labor aterm labor. 1 person with age $>35$ years trimester II multiparous with job as IRT, not with history of vaginal discharge, birth history with infant birth weight between 2500-4000 gram and with aterm birth. In direct examination germ-painting is done to look for elements of the fungus namely pseudohifa and budding yeast cells characteristic for candida [7]. Mothers who have pathological vaginal discharge caused by Candida albicans / caused by personal hygiene and also in pregnancy saan occur estrogen and weight increase hormone so that increased production of sweat and cause moisture in the vagina that trigger the growth of microorganisms. Other conditions that trigger the growth of Candida albicans in the vaginal area of the occurrence of $\mathrm{PH}$, from $\mathrm{PH}$ acid to $\mathrm{PH}$ bases / normal, loss of acid $\mathrm{PH}$ concentration into predisposing factors. The incidence of Candida albicans fungi infection causes the occurrence of infection as well as DM disease during pregnancy, 
hormone progesterone / or antibiotic treatment and age and immunology. It is an endogenous factor whereas exogenous factors such as hygiene and humidity [7].

These results are reinforced by a study conducted by [6] under the title Candida Identification. On the vaginal rubbing of pregnant women in obstetric polyclinics and obstetric diseases of Makassar pilgrim hospital which states that 9 people $(60 \%)$ of 15 pregnant women who checked in the hospital were positively infected with Candida. Positive results on Gram examination are characterized by purple (gram-positive) and blastospores in a 100x magnification microscope (Aminudin, 2009). Age and immunology, exogenous factors such as climate and humidity cause persipitation, skin hygiene and contact with patients [7].

The germ tube test is a germination on a protein containing medium (eg serum) used to determine albicans or non-Candida albicans species. Positive result on Germ tube test occurs sprout formation of blastospores in the form of small tubes, Candida albicans will form the seed tube in 2-3 hours when placed in serum at $37^{\circ} \mathrm{C}$. To be able to cause disease, Candida albicans must be able to overcome the body's defenses that are neither specific nor specific and have the ability to stick or penetrate the mucous membranes and skin, adjust to the environment, breed and cause damage or tissue reactions such as inflammation. When Candida albicans penetrates the skin or mucous membranes exogenously or endogenously in the vagina will change the acidity of the vagina thus increasing whiteness [6].

This result is supported by the previous research conducted by [8] with the title of Candida albicans identification in pregnant women's vaginal fluid at midwife practice clinic with germ tube method mentioned that from 20 samples stated positive of Candida albicans infection, $85 \%$ of them are caused by Candida albicans. The occurrence of positive results showed the lack of personal hygiene, especially for the cleanliness of reproductive organs and the environment and the negative result caused by pregnant women before the examination has cleaned the vaginal area and dry it well and has done good personal hygiene and environment. Attitudes and hygiene behaviors that can not be properly applied by pregnant women such as, dirty water used to clean the vagina, do not dry the vaginal area well after the waste water, dirty underwear or not replaced regularly can also increase susceptibility to infection. String or nylon-tight underwear can cause the vagina to become damp, providing an ideal environment for fungal growth that will affect fungal infections, especially Candida albicans. Repeated pairing, use of antibiotics, irritating soaps, vaginal spray and water spray will also affect Candida albicans yeast infections. In addition, an unhealthy diet can lead to decreased immune system, making it easier to infect Candida albicans fungi.
The results of this study also proved that the third trimester pregnant women positively infected with Candida albicans as much as 2 samples. In pregnant women are susceptible to infection, because the immune system of pregnant women will usually decrease and increase the need for metabolism [9]. In addition, estrogen also affects positive results because estrogen hormone is thought to increase Candida albicans adhesion in the vaginal epithelium and directly increase the virulence of yeast [1]. This result is supported by previous research conducted by Atmasari in 2011 with the title of Candida albicans identification in pregnant women's vaginal fluid at midwife practice clinic with germ tube method mentioned that of 30 samples of vaginal fluid specimens of pregnant women, $88,89 \%$ of Candida albicans fungi infect Trimester pregnant women III. From the positive results in the first, second and third trimesters, the third trimester pregnant women had the highest infection among the other trimesters. This may be because in the third trimester there is an increase in estrogen hormone and the growing weight of pregnant women that will increase the production of sweat that will cause moisture, espectially in the vaginal area [6].

\section{References}

[1] Amelia, S. 2009, Penyembuhan penyakit reproduksi perempuan. Indocamp. Jakarta.

[2] Sunyoto 2014. Pentingnya Menjaga Organ Kewanitaan. Indeks Jakarta.

[3] Lubis, I., B., G. 2013. Memahami Kesehatan Reproduksi Wanita. Jakarta EGC.

[4] Siregar, 2012. Pengalaman Ibu Hamil yang Mengalami Hiperemesis Gravidarum pada Trimester I di RSUD Dr. Pirngadi Kota Medan Tahun 2011.http://repository.usu.ac. id/bitstream/123456789/41260/6/Abstract.

[5] Dewi Komala Ni Made, Nursari Made, Idayani Sri. 2014. Identifikasi Jamur Candida Albicans pada Usap Vagina Ibu Hamil Trimester I,II, dan III di Puskesmas Denpasar. Klinika Laboratory. 1(2):137-142.

[6] Widarti, 2011. Identifikasi Candida albicans pada Usap Vagina Ibu Hamil di Poliklinik Kebidanan dan Penyakit Kandungan Rumah Sakit Haji Makasar. http://isjd.pdii.lipi.go.id/index.php/Search.html?act=tampil \&id=68243 Diakses tanggal 12 Mei 2014.

[7] Simatupang. 2009. Penyakit flour albus berdasarkan penyebabnya. Perawatan kebidanan. Jakarta EC.

[8] Atmasari. 2011. Konsep Personal Hygiene. hidayat 2.wordpress.com Diakses tanggal 25 april 2013.

[9] Ritonga, 2011. Hambatan Ekstrak Etanol Gel Lidah Buaya (Aloe Vera) Terhadap Pertumbuhan Jamur Candida Albicans Isolat Vagina 218 Sv Secara In Vitro.http://www.sharepdf.com/Hambatan20Ekstrak20Etan ol201Idah 20Buaya20terhadap20P ertumbuhan 20Jamur 20candida 20al bicans com Diakses tanggal 25 april 2013. 